\title{
Does home visiting improve parenting and the quality of the home environment? A systematic review and meta analysis
}

\author{
Denise Kendrick, Ruth Elkan, Michael Hewitt, Michael Dewey, Mitch Blair,
} Jane Robinson, Debbie Williams, Kathy Brummell

\begin{abstract}
Aims-To evaluate the effectiveness of home visiting programmes on parenting and quality of the home environment.

Design-Systematic review of the literature of randomised controlled trials and quasi-experimental studies evaluating home visiting programmes involving at least one postnatal visit.

Subjects-Thirty four studies reported relevant outcomes; 26 used participants considered to be at risk of adverse maternal or child health outcomes; two used preterm or low birth weight infants; and two used infants with failure to thrive. Only eight used participants not considered to be at risk of adverse child health outcomes.

Results-Seventeen studies reported Home Observation for Measurement of the Environment (HOME) scores, 27 reported other measures of parenting, and 10 reported both types of outcome. Twelve studies were entered into the meta analysis. This showed a significant effect of home visiting on HOME score. Similar results were found after restricting the analyses to randomised controlled trials and to higher quality studies. Twenty one of the 27 studies reporting other measures of parenting found significant treatment effects favouring the home visited group on a range of measures.

Conclusions-Home visiting programmes were associated with an improvement in the quality of the home environment. Few studies used UK health visitors, so caution must be exercised in extrapolating the results to current UK health visiting practice. Further work is needed to evaluate whether UK health visitors can achieve similar results. Comparisons with similar programmes delivered by paraprofessionals or community mothers are also needed.

(Arch Dis Child 2000;82:443-451)
\end{abstract}

Keywords: home visiting; parenting; home environment; health visitor

Health, University of Nottingham

M Blair

Correspondence to:

Dr Kendrick

email: denise.kendrick@

nottingham.ac.uk

Accepted 2 February 2000 behaviour are related to parenting style. ${ }^{12}$ There has therefore been a growing interest in methods of supporting parents and improving
Parenting has received increasing attention over recent years, with evidence that adverse child health outcomes such as antisocial parenting skills to reduce the frequency of such adverse outcomes. ${ }^{3-6}$ Recent changes in government policy have provided funding for enhancing the role of the health visitor in this area and also for "Sure Start", a support programme for parents delivered by outreach workers. $^{5}$

It has been argued that improving the parenting given to vulnerable children is an important child health strategy, and that health visitors are ideally placed, and capable of, detecting poor parenting at an early stage. ${ }^{4}$ This is encapsulated in the enhanced role of the health visitor as described in Supporting families. ${ }^{5}$ We have undertaken this systematic review as part of a larger systematic review assessing the effectiveness of home visiting. We considered it important to review the existing literature relating to parenting and the quality of the home environment in view of the difficulty of undertaking evaluations of the effectiveness of home visiting, the resource intensive nature of these programmes, and the recent emphasis on improving parenting within health care policy. As the larger systematic review has covered a range of maternal and child health outcomes, we have also been able to assess the effect of home visiting on other aspects of maternal and child health that may be related to parenting.

\section{Methods}

The systematic review aimed to assess the effectiveness of home visiting programmes on a range of maternal and child health outcomes. The results relating to parenting and the quality of the home environment are presented here.

SEARCH STRATEGY

We searched Medline from 1966 to July 1996; Cinahl from 1982 to July 1996; Embase from 1980 to October 1996; and the Cochrane Library. The Medline search involved four searches. Firstly, MeSH methodology terms ("clinical trials", "randomised controlled trials", "comparative", "evaluative", "followup", and "prospective") were combined with $\mathrm{MeSH}$ subject terms ("Community Health Nursing") using the search strategy devised by Dickersin et al. ${ }^{7}$ Secondly, MeSH methodology terms were combined with the text words "health visit\$", "home visit\$", and "domiciliary visit\$". Thirdly, the subject $\mathrm{MeSH}$ terms were used in combination with text words relating to methodology 
("evaluation", "effectiveness", and "outcome"). Fourthly, the text words relating to methodology and subjects were used in combination.

The Embase search included two searches: the first using the index terms "clinical trial", "clinical study", "evaluation and follow up", and "economics" combined with the index term "health visitor"; and the second using the text words "effectiveness", "evaluation", and "outcome" combined with the text words "home + visit" and "domiciliary + visit". The Cinahl search used the same text words as the second Embase search, but also included the index term "health visitor".

We hand searched the journal Health Visitor from 1982 to 1997 and the reference lists of reviews of the literature in the field reporting outcomes relevant to parenting..$^{8-12} \mathrm{Key}$ individuals and organisations were contacted to trace unpublished work, and advertisements were also placed in relevant journals to identify unpublished work.

INCLUSION CRITERIA

Articles were included if they were randomised controlled trials or quasi-experimental studies including a control group that evaluated a home visiting programme. The home visiting programme had to include at least one postnatal home visit. The personnel delivering the home visiting had to undertake tasks which were within the remit of British health visiting (for example, social support, education on child development and child health, facilitation of mother-child interaction, and promotion of parenting) and the study had to report outcomes relevant to British health visiting (for example, measures of the quality of the home environment, measures of parent-child interaction, attitudes towards child and child rearing practices).

SELECTION OF STUDIES TO BE INCLUDED IN THE REVIEW

The full text of all studies identified by the search were obtained. One researcher (RE) reviewed all studies for inclusion criteria and for relevance. Where there were doubts about relevance relating to whether the tasks undertaken fell within the remit of British health visiting, or whether the outcomes were relevant to British health visiting, the health visiting members of the study team (JR, KB, DW) reviewed the article and reached a joint decision.

DATA EXTRACTION

For each study, the following data were extracted: purpose of study, experimental design, sample size determination, description and suitability of subjects, randomisation and stratification, comparison group usage, procedures for management, blinding, subject attrition, evaluation of subjects, and management. The number of participants in each treatment group was extracted, along with the mean and standard deviation for continuous variables. Where such data were not available, the lead author was written to, or contacted by email, and asked to provide further information. Where results from the same intervention study have been reported in more than one paper, the study has only been counted once. The quality of the studies included in the review was assessed by the Reisch scale, which is scored between 0 and 1 , with higher scores representing higher quality reports. ${ }^{13}$ Three members of the research team quality scored the articles (DK, MH, MB), blind to the authors, results, and conclusions of the studies. The Reisch scale was applied to 19 articles by each of the three reviewers to assess inter-rater reliability. The correlation coefficients between the pairs of raters were $0.71,0.79$, and 0.82 . The overall intraclass correlation coefficient was $0.74(95 \%$ confidence interval 0.52 to 0.88).

OUTCOME MEASURES

Parenting and the quality of the home environment have been measured in a variety of ways in the studies we reviewed. The standard measure used most commonly was the Home Observation for Measurement of the Environment inventory (HOME). ${ }^{14}$ This is administered by an interviewer within the family home and is based on observations of the interviewer. The infant-toddler version of the HOME inventory consists of six subscales measuring aspects of the quality of the home environment in relation to parenting. These include emotional and verbal responsivity of the mother, avoidance of restriction and punishment, organisation of the environment, provision of appropriate play materials, maternal involvement with the child, and opportunities for variety within the daily routine. Results can be presented as mean score for the overall scale, or for separate subscales. The majority of studies reporting HOME scores, did not report the mean plus standard deviation (table 2), hence the meta analysis was undertaken using Fisher's method. This represents a conservative estimate of the overall effect of home visiting as it is based only on the $p$ values given in each article. We have therefore not been able to produce a figure for an overall improvement in the HOME score across the studies included in the meta analysis. Those studies reporting other measures of parenting and the quality of the home environment have not been included in the meta analysis.

\section{Results}

In total 1218 references were found from the searches; 102 studies fulfilled the inclusion criteria, of which 34 reported outcomes relating to parenting and the quality of the home environment. ${ }^{15-48}$ 49-51 Seventeen studies reported HOME scores, ${ }^{15-33} 27$ studies reported other measures of parenting, ${ }^{151619-22} 25^{26} 6^{32-51}$ and 10 studies reported both HOME scores and other measures of parenting. ${ }^{15}{ }^{16} 19-222526303233$ Table 1 presents the characteristics of the studies reporting HOME scores. Table 2 presents the evaluation periods, outcome measures, and the results of each study. Table 3 presents the characteristics 
Table 1 Characteristics of studies reporting HOME scores, including those also reporting other measures of parenting

\begin{tabular}{|c|c|c|c|c|c|}
\hline Reference & $\begin{array}{l}\text { Group } \\
\text { allocation }\end{array}$ & Score & Intervenors & Participants & Intervention \\
\hline $\begin{array}{l}\text { *Field et al (1980), } \\
\text { USA }^{15}\end{array}$ & Random & 0.52 & $\begin{array}{l}\text { Trained teenage } \\
\text { black female } \\
\text { students }\end{array}$ & $\begin{array}{l}\text { Black teen mothers, low } \\
\text { socioeconomic status, } \\
\text { preterm infants }\end{array}$ & $\begin{array}{l}\text { Home visit }(\mathrm{n}=30) .2 \text { visits per week birth- } 4 \text { months; then one } \\
\text { per month. Control: no home visit }(\mathrm{n}=30) \\
\text { Intervention = education on child development, child rearing, } \\
\text { teach stimulation of child, facilitate mother-child interaction }\end{array}$ \\
\hline $\begin{array}{l}\text { *Larson }(1980), \\
\text { Canada }^{16}\end{array}$ & Sequential & 0.39 & $\begin{array}{l}\text { Psychology } \\
\text { graduates }\end{array}$ & Working class families & $\begin{array}{l}\text { A: pre- and postnatal home visits }(n=35) .4 \text { postnatal visits age } \\
1-6 \text { weeks, } 5 \text { visits age } 6 \text { weeks- }-15 \text { months } \\
\text { B: postnatal home visits }(n=36) .7 \text { visits age } 6 \text { weeks }-6 \text { months, } \\
3 \text { visits age } 6-15 \text { months } \\
\text { Control: no home visits }(n=44) \\
\text { Intervention }=\text { counselling and advice on care tasking, } \\
\text { mother-infant interaction, social status, child development }\end{array}$ \\
\hline $\begin{array}{l}\text { *Field et al (1982), } \\
\text { USA }^{17}\end{array}$ & Random & 0.52 & Teachers & $\begin{array}{l}\text { Black teen mothers, low } \\
\text { socioeconomic status, } \\
\text { term infants }\end{array}$ & $\begin{array}{l}\text { A: home visit parent training }(n=34) \text {. Biweekly visits for } 6 \\
\text { months, B: nursery parent training }(n=36) \text { four hours per day } \\
\text { for } 6 \text { months } \\
\text { Control: No parent training }(n=35) \\
\text { Intervention A: infant stimulation care taking, mother-infant } \\
\text { interaction exercises. B: parent training, job training }\end{array}$ \\
\hline $\begin{array}{l}\text { ^Barrera et al (1986), } \\
\text { Canada }^{18}\end{array}$ & Random & 0.55 & $\begin{array}{l}\text { Infant parent } \\
\text { therapists }\end{array}$ & Infants born 1979-81 & $\begin{array}{l}\text { A: home visits }(n=16) .1 \text { visit per week age } 0-4 \text { months, then } 1 \\
\text { visit per } 2 \text { weeks age } 5-9 \text { months } \\
\text { B: home visits }(n=22) .1 \text { visit per month age } 9-12 \text { months } \\
\text { Control A: no home visits }(n=21 \text {, preterm infants). Control B: } \\
\text { no home visits }(n=24 \text {, full term infants) } \\
\text { Intervention A: improve child's development. Intervention B: A + } \\
\text { improve maternal-child interaction }\end{array}$ \\
\hline $\begin{array}{l}\text { Olds et al }(1986,1994) \text {, } \\
\text { USA }^{1920}\end{array}$ & Random & 0.50 & Nurses & $\begin{array}{l}\text { Children born to } \\
\text { teenagers, unmarried, low } \\
\text { socioeconomic status }\end{array}$ & $\begin{array}{l}\text { A: Screening at } 12 \text { and } 24 \text { months of age, no home visits }(n=90) \text {. } \\
\text { B: A + transport to clinics, no home visits }(n=94) \\
\text { C: } B+\text { antenatal home visits }(n=100) \text {. Mean } 9 \text { visits in pregnancy } \\
\text { D: } C+\text { postnatal home visits }(n=116) \text {. Mean combined ante- } \\
\text { and postnatal home visits }=23 \\
\text { Intervention }(C \text { and } D)=\text { parent education, promotion of } \\
\text { informal maternal support, linkage with community services }\end{array}$ \\
\hline $\begin{array}{l}\text { Barnard et al } \\
\quad(1988) / \text { Booth et al } \\
\quad(1989), \text { USA }^{22} 22\end{array}$ & Random & 0.29 & Nurses & $\begin{array}{l}\text { Pregnant and postpartum } \\
\text { women lacking social } \\
\text { support }\end{array}$ & $\begin{array}{l}\text { Home visit mental health model }(\mathrm{n}=68) \text {. Mean } 19 \text { visits from } 22 \\
\text { weeks gestation to } 12 \text { months of age } \\
\text { Control: home visit information/resource utilisation model } \\
(\mathrm{n}=79) . \text { Mean } 14 \text { visits }(22 \text { weeks gestation- } 12 \text { months) } \\
\text { Intervention: mental health model = therapeutic relation with } \\
\text { pregnant women to deal with interpersonal situations and } \\
\text { problem solving. Information/resource model information on } \\
\text { physical and developmental health of child }\end{array}$ \\
\hline $\begin{array}{l}\text { Osofsky et al (1988), } \\
\text { USA }^{23}\end{array}$ & Random & 0.38 & $\begin{array}{l}\text { Community } \\
\text { women }\end{array}$ & $\begin{array}{l}\text { Teenage, unmarried } \\
\text { mothers }\end{array}$ & $\begin{array}{l}\text { Home visits }+ \text { telephone help line }+ \text { drop in centre. Weekly visits } \\
\text { for } 1 \text { st month, then monthly to } 30 \text { months of age } \\
\text { Control: no home visits. Total } n=130 \text { (intervention }+ \text { control, } \\
\text { figures not given for each arm) } \\
\text { Intervention = teaching child stimulation discussion of parenting } \\
\text { issues and maternal problems }\end{array}$ \\
\hline $\begin{array}{l}{ }^{\star} \text { Infante-Rivard } \text { et al } \\
\quad(1989), \text { Canada }^{24}\end{array}$ & Random & 0.46 & $\begin{array}{l}\text { Public health } \\
\text { nurses }\end{array}$ & $\begin{array}{l}\text { Socioeconomically } \\
\text { disadvantaged families }\end{array}$ & $\begin{array}{l}\text { Home visits }(\mathrm{n}=21) .3 \text { prenatal visits }+5 \text { postnatal visits. Control: } \\
\text { no home visits }(\mathrm{n}=26) \\
\text { Intervention }=\text { counselling, teaching about child development, } \\
\text { child health and behaviour }\end{array}$ \\
\hline $\begin{array}{l}\text { *Wasik et al (1990), } \\
\text { USA }^{25}\end{array}$ & Random & 0.52 & $\begin{array}{l}\text { Day care teachers, } \\
\text { social workers, } \\
\text { nurses }\end{array}$ & $\begin{array}{l}\text { Children at risk of } \\
\text { cognitive difficulties }\end{array}$ & $\begin{array}{l}\text { A: home visits + child development programme }(n=16) \text {. Weekly } \\
\text { visits first } 3 \text { years of life } \\
\text { B: home visits }(n=25) \text {. Weekly visits for } 3 \text { years. Control: no } \\
\text { home visits/child development programme }(n=23) \\
\text { Intervention = promotion of parent problem solving strategies }\end{array}$ \\
\hline $\begin{array}{l}\text { *Huxley and Warner } \\
(1993), \text { USA }^{26}\end{array}$ & Non-random & 0.18 & Nurses & $\begin{array}{l}\text { Families referred to } \\
\text { tri-agency intervention } \\
\text { programme }\end{array}$ & $\begin{array}{l}\text { Home visits }(n=20) \text {. Visit frequency dependent on need. Control: } \\
\text { routine care }(n=20) \\
\text { Intervention = prevention of parent dysfunction, education in } \\
\text { maternal and child health }\end{array}$ \\
\hline $\begin{array}{l}\text { ^Black et al (1994), } \\
\text { USA }^{27}\end{array}$ & Random & 0.57 & Community nurses & $\begin{array}{l}\text { Mothers with prenatal } \\
\text { cocaine/heroin use }\end{array}$ & $\begin{array}{l}\text { Home visits }(\mathrm{n}=31) .2 \text { prenatal visits. Biweekly visits from } \\
\text { birth-18 months of age. Control: no home visits }(\mathrm{n}=29) \\
\text { Intervention = maternal support, promote parenting, child } \\
\text { development, use of resources and advocacy }\end{array}$ \\
\hline $\begin{array}{l}\text { *Casey et al (1994), } \\
\text { USA }^{28}\end{array}$ & Random & 0.64 & $\begin{array}{l}\text { Paediatrician, } \\
\text { nurse, social worker }\end{array}$ & $\begin{array}{l}\text { Infants with failure to } \\
\text { thrive }\end{array}$ & $\begin{array}{l}\text { Home visits }(n=67) .1 \text { visit per week year } 1 \text {. One visit per } 2 \text { weeks } \\
\text { years } 2-3 \text {. Control: no home visits }(n=113 \text { ) } \\
\text { Intervention }=\text { cognitive, language, social development, help with } \\
\text { managing parental self identified problems }\end{array}$ \\
\hline $\begin{array}{l}\text { Marcenko and Spence } \\
\text { (1994), USA }{ }^{29}\end{array}$ & Random & 0.25 & Lay home visitors & $\begin{array}{l}\text { Pregnant and postpartum } \\
\text { women at risk of child } \\
\text { abuse }\end{array}$ & $\begin{array}{l}\text { Home visits }(n=125) \text {. Prenatal } 1 \text { visit per } 2 \text { weeks. Postnatal } \\
\text { weeks } 1-6 \text { weekly visit, weeks } 7-26 \\
1 \text { visit per } 2 \text { weeks, weeks } 27-52 \text { monthly visit. Control: no home } \\
\text { visits }(n=100) \text {. } \\
\text { Intervention = peer support, identify service needs, health } \\
\text { education, parent training }\end{array}$ \\
\hline $\begin{array}{l}{ }^{\star} \text { Black et al (1995), }_{\text {USA }^{30}} \\
\text { (19) }\end{array}$ & Random & 0.61 & Lay home visitors & $\begin{array}{l}\text { Children with failure to } \\
\text { thrive }\end{array}$ & $\begin{array}{l}\text { Home visits + clinics }(\mathrm{n}=64) \text {. Weekly visits for one year. Control: } \\
\text { clinics only }(\mathrm{n}=66) \\
\text { Stratified by age of child: younger group }=0-12 \text { months; older } \\
\text { group }=21.1-24.9 \text { months } \\
\text { Intervention = maternal support, promotion of parenting, child } \\
\text { development, use of resources and advocacy }\end{array}$ \\
\hline $\begin{array}{l}\text { Shapiro (1995), } \\
\text { Canada }^{31}\end{array}$ & Random & 0.18 & $\begin{array}{l}\text { Community nurse } \\
\text { and home maker }\end{array}$ & $\begin{array}{l}\text { Low birth weight } \\
\text { newborns }\end{array}$ & $\begin{array}{l}\text { Home visits }(\mathrm{n}=50) \text {. Mean } 3.8 \text { visits }+8.4 \text { telephone contacts up } \\
\text { to } 8 \text { weeks post discharge } \\
\text { Control: routine home visits }(\mathrm{n}=50) . \text { Mean } 1.4 \text { visits }+1.9 \\
\text { telephone contacts up to } 8 \text { weeks post discharge } \\
\text { Intervention = early discharge from hospital, personal maternal } \\
\text { support, respite care, help with infant care, light housekeeping, } \\
\text { information on infant care }\end{array}$ \\
\hline
\end{tabular}


Table 1 cont'd

\begin{tabular}{|c|c|c|c|c|c|}
\hline Reference & $\begin{array}{l}\text { Group } \\
\text { allocation }\end{array}$ & Score & Intervenors & Participants & Intervention \\
\hline $\begin{array}{l}{ }^{\star} \text { Kitzman et al } \\
\text { (1997), USA }\end{array}$ & Random & 0.79 & Nurses & $\begin{array}{l}\text { African-American } \\
\text { women, 1st pregnancy } \\
<29 \text { weeks gestation, }>1 \\
\text { sociodemographic risk } \\
\text { factors }\end{array}$ & $\begin{array}{l}\text { Home visits }(\mathrm{n}=228) \text {. Mean number prenatal visits }=7 \text {, mean number } \\
\text { from birth to age } 24 \text { months }=26 \\
\text { Control: no home visit, but free transport for prenatal and child } \\
\text { development services }(\mathrm{n}=515) \\
\text { Intervention = helping women improve health related behaviour, child } \\
\text { care, and life course development }\end{array}$ \\
\hline $\begin{array}{c}{ }^{\star} \text { Davis and Spurr } \\
(1998), \mathrm{UK}^{33}\end{array}$ & Non random & 0.54 & $\begin{array}{l}\text { Health visitors, } \\
\text { medical officers }\end{array}$ & $\begin{array}{l}\text { Preschool children, } \\
\text { multiple psychosocial } \\
\text { problems }\end{array}$ & $\begin{array}{l}\text { Intervention: home visits and routine community services }(n=87) \text {. } \\
\text { Weekly } 1 \text { hour sessions. Mean } 6 \text { visits } \\
\text { Control: routine community services }(n=38)\end{array}$ \\
\hline
\end{tabular}

^Studies whose outcome measures have been included in the meta analysis.

of studies reporting other parenting outcomes. Table 4 presents the evaluation periods, outcome measures, and the results of each study.

Twelve of the 17 studies reporting HOME scores were included in the meta analysis. ${ }^{15-1824-28} 303233$ Eleven of the 12 studies reported total HOME scores, ${ }^{16-18} 24-28303233$ and one reported a subscale score only. ${ }^{15}$ Five studies did not report either the mean and standard deviation of the HOME scores, or a $\mathrm{p}$ value and therefore could not be included in the meta analysis. ${ }^{19-23} 2931$ Fourteen effect sizes were extracted from the 12 studies (two studies reported outcomes for two age groups separately ${ }^{30}{ }^{33}$ ) and entered into the meta analysis using Fisher's method. A highly significant result was obtained suggesting home visiting was effective in improving the quality of the home environment as measured by the HOME score $\left(\chi^{2}=126.9,28 \mathrm{df}\right.$, $\mathrm{p}<0.001)$. Restricting the analysis to randomised studies produced similar findings $\left(\chi^{2}=70.6,20 \mathrm{df}, \mathrm{p}<0.001\right)$. Restricting the analyses to studies with a quality score of 0.5 or above also produced similar findings $\left(\chi^{2}=93.3,22 \mathrm{df}, \mathrm{p}<0.001\right)$.

The five studies using HOME scores as an outcome measure which were not included in the meta analysis included four which did not report any data relating to the HOME scores. ${ }^{21-23} 2931$ Barnard et al claimed intervention group families had improved HOME scores at 12 and 24 months, ${ }^{21}{ }^{22}$ Osofsky et al reported results relating only to a subgroup analysis within the intervention group, ${ }^{23}$ Marcenko and Spence reported no significant difference between treatment groups, ${ }^{29}$ and Shapiro claimed a significant improvement in HOME scores in the intervention group at 12 months. ${ }^{31}$ Olds et al reported non-significant differences in mean HOME scores between the treatment groups at 34 and 46 months. ${ }^{19} 20$

Table 4 shows that the 27 studies reporting other measures of parenting used a wide range of outcome measures. Seventeen studies reported outcomes related to assessing the interaction between the mother and child. Twelve of these studies reported significantly better interaction between mother and child in the intervention group, using a range of measures ${ }^{15} 1619203336374143-4651$ (shown in tables 2 and 4) including greater observed involvement and reciprocal interaction, ${ }^{19} 2043$ responsiveness to the child's behaviour, ${ }^{16}$ the quantity and type of interaction between mother and child, ${ }^{36}{ }^{44}$ greater observed conversation with the child, ${ }^{43}$ lower rates of reported difficulties in the mother-infant relationship, ${ }^{51}$ greater positive feedback and more praise of the child, and fewer negative interactions between mother and child, ${ }^{3645}$ and a more positive attitude towards the child. ${ }^{33}$ Barker and Anderson reported receipt of intervention to be significantly associated with cognitive and educational environment within the home in some, but not all of the geographical areas evaluating the Child Development Programme. ${ }^{46}$

Five studies found no significant difference between the intervention and control groups in terms of mother-child attachment, maternal interaction with child, parental warmth, verbal praise, and engaging in shared activities with the child. ${ }^{18} 2122303248$

Seven studies reported outcomes assessing parental attitudes and actions towards child discipline. ${ }^{15} 19202526353644$ Three studies reported outcomes favourable to the intervention group; these included significantly less negative or punitive attitudes towards child rearing, ${ }^{15} 26$ and more "appropriate" answers to questions regarding the parents' handling of aggressive behaviour in their child. ${ }^{36}$ Four studies did not find a positive effect in the home visited group on preference for the use of positive as opposed to negative motivation in disciplining the child, ${ }^{35}$ the extent to which the parents were authoritarian in their attitudes to child rearing, ${ }^{25}$ or use of physical punishment. ${ }^{19} 2044$

Five studies reported parents' developmental expectations of their child. ${ }^{26} 35383943$ Four reported significant differences favouring the intervention group in terms of more positive or more realistic expectations. ${ }^{3538} 3943$ Two studies reported outcomes related to mothers' teaching ability, both of which found intervention group mothers were significantly more involved in the child's schooling or provided more stimulation likely to promote future success at school. ${ }^{3642}$ Five studies reported parental stimulation of the child using books, games, or toys. ${ }^{19} 2035364950$ Three reported significantly better outcomes in the intervention group. ${ }^{35} 3649$ The other outcomes reported in table 4 were only reported for one or two studies.

In total, six of the 27 studies reporting other measures of parenting failed to show positive results in the intervention group. ${ }^{18212225303240}$ 
Table 2 Evaluation period, outcome pleasures, and HOME scores

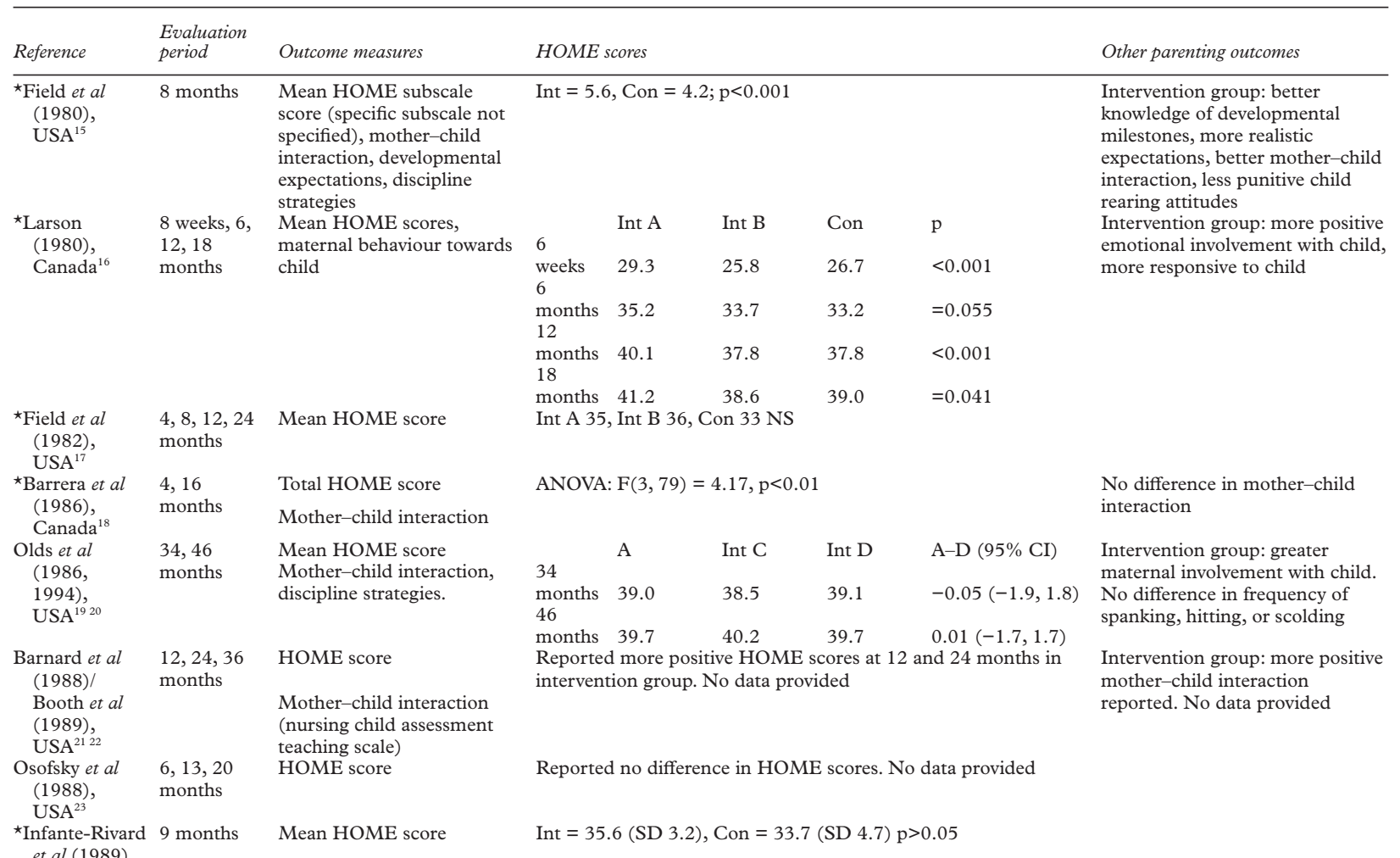

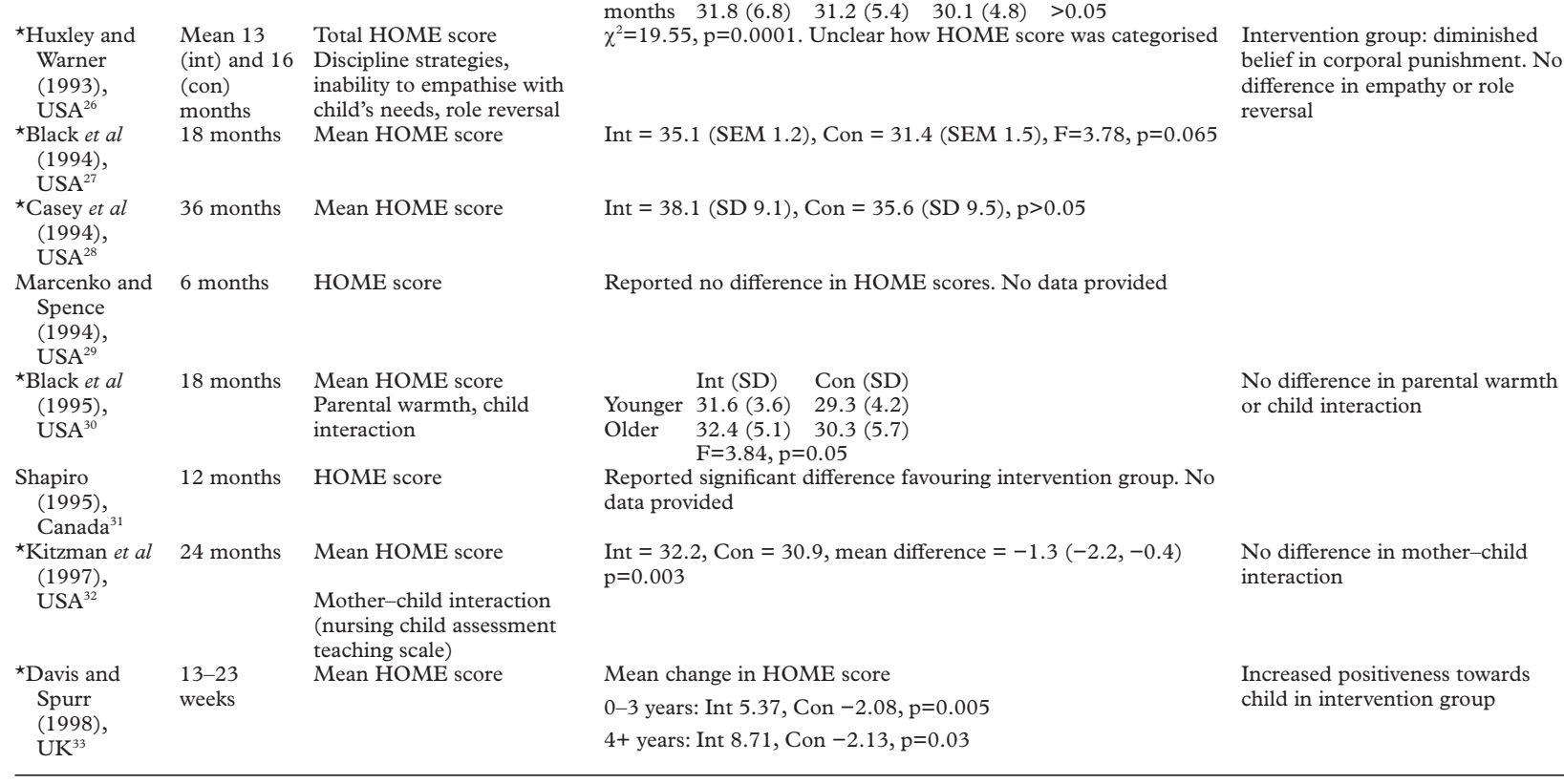

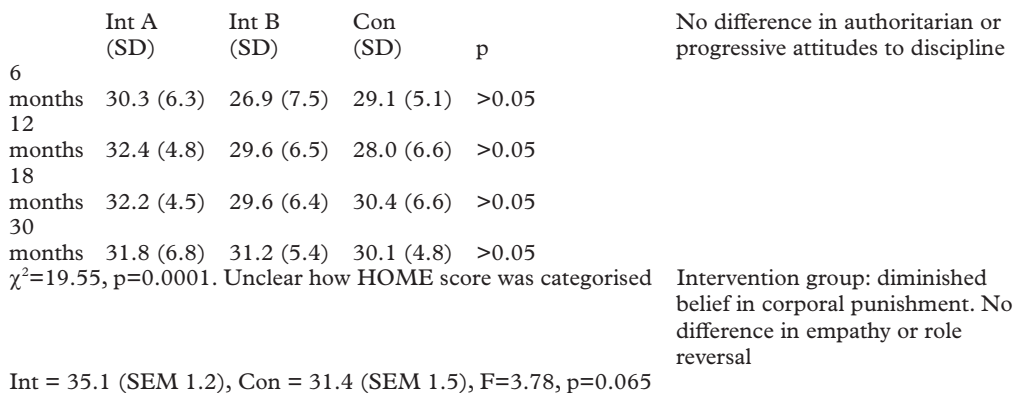
$\begin{array}{cll}\text { Wasik et al } & 6,12,18, & \text { Mean HOME score } \\ (1990), & 30 \text { months } & \text { Discipline strategies }\end{array}$ 
Table 3 Characteristics of studies reporting other measures of parenting

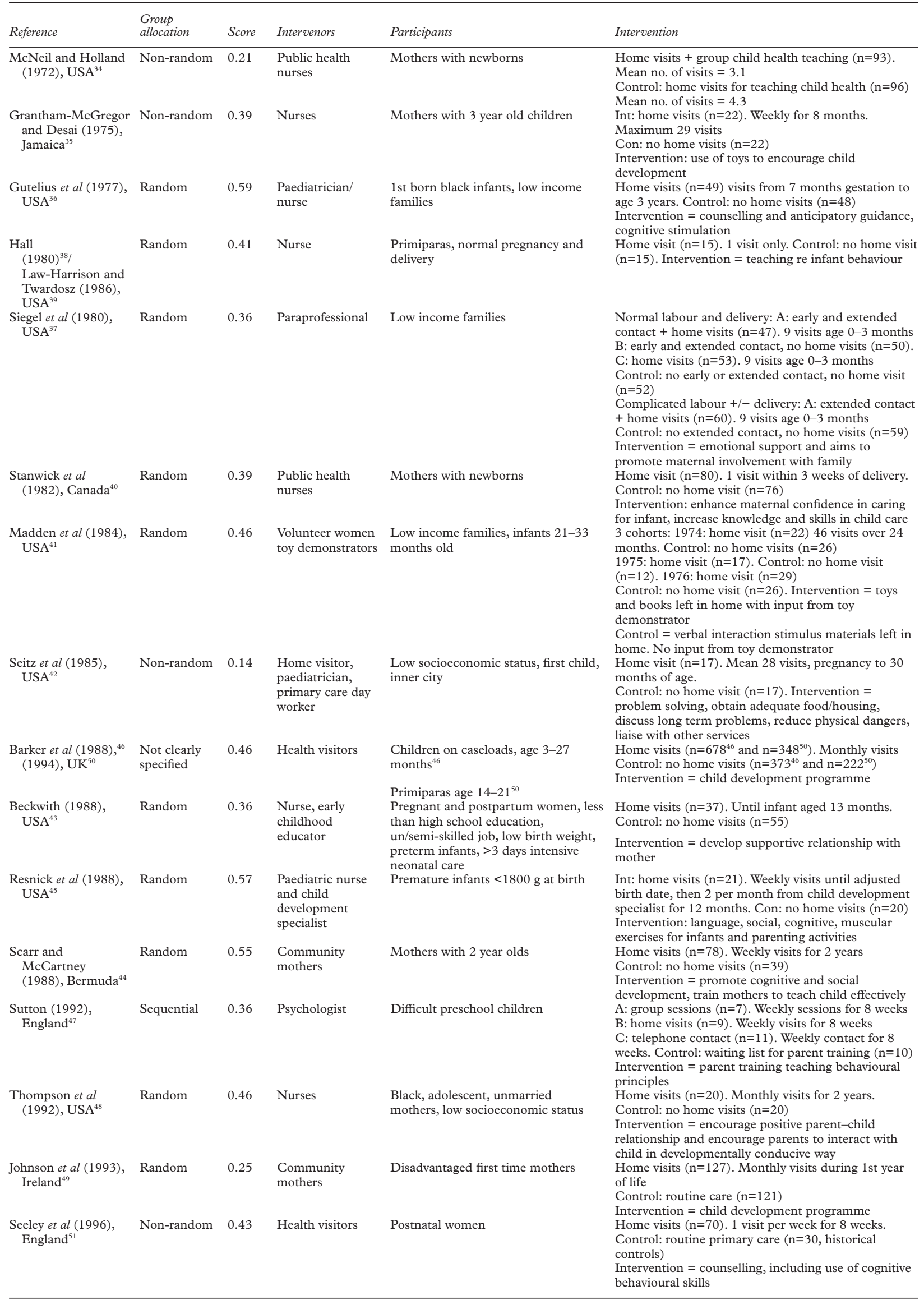


Table 4 Evaluation period, outcome measures and parenting outcomes

\begin{tabular}{|c|c|c|c|}
\hline Reference & $\begin{array}{l}\text { Evaluation } \\
\text { period }\end{array}$ & Outcome measures & Parenting outcomes \\
\hline $\begin{array}{l}\text { McNeil and Holland } \\
\text { (1972), USA }\end{array}$ & $18-21$ months & Knowledge of child health & $\begin{array}{l}\text { Mean (SD) knowledge score. } \text { Int }=89.8(18.7), \text { Con }=76.4(16.7) . t=3.9, \\
\mathrm{p}<0.05\end{array}$ \\
\hline $\begin{array}{l}\text { Grantham-McGregor } \\
\text { and Desai (1975), } \\
\text { Jamaica }^{35}\end{array}$ & 8 months & $\begin{array}{l}\text { Playing and talking to child, awareness of } \\
\text { child's mental abilities, awareness of } \\
\text { educational value of toys, reading to child, } \\
\text { positive motivation, time spent with child }\end{array}$ & $\begin{array}{l}\text { Playing and talking to child, } \mathrm{p}<0.05 \text {; awareness of child's mental abilities, } \\
\mathrm{p}<0.05 \text {; awareness of educational value of toys, } \mathrm{p}<0.05 \text {. No differences in } \\
\text { other outcomes between groups. Data not presented for any outcomes, only } \\
\text { significance test results }\end{array}$ \\
\hline $\begin{array}{l}\text { Gutelius et al (1977), } \\
\text { USA }^{36}\end{array}$ & 24,36 months & $\begin{array}{l}\text { Mother-child interaction } \\
\text { Appropriately handling aggression } \\
\text { Promoting future school success } \\
\text { Daily use of praise }\end{array}$ & $\begin{array}{l}\text { Int }=20 / 46, \text { Con }=6 / 45, \mathrm{p}<0.01 \\
\text { Int }=15 / 44, \text { Con }=6 / 42, \mathrm{p}<0.05 \\
\text { Int }=29 / 44, \text { Con }=13 / 42, \mathrm{p}<0.01 \\
\text { Int }=37 / 44, \text { Con }=27 / 42, \mathrm{p}<0.05\end{array}$ \\
\hline $\begin{array}{l}\text { Hall }(1980)^{38} / \\
\text { Law-Harrison and } \\
\text { Twardosz (1986), } \\
\text { USA }^{39}\end{array}$ & 1 month & Neonatal Perception Inventory & $\begin{array}{ll}\text { Mean }(\text { variance }) & \text { NPI 1: Int }=1.27(3.31), \text { Con }=1.87(2.92), p=0.05 \\
\text { score } & \text { NPI 2: Int }=2.8(6.8), \text { Con }=2.14(15.2), p=0.05\end{array}$ \\
\hline $\begin{array}{l}\text { Siegel et al (1980), } \\
\quad \text { USA }^{37}\end{array}$ & 4,12 months & $\begin{array}{l}\text { Acceptance } \\
\text { Interaction/stimulation }\end{array}$ & $\begin{array}{l}\text { Acceptance } 4 \text { months, } \mathrm{p}<0.05 ; 12 \text { months, NS } \\
\text { Interaction/stimulation } 4 \text { months, NS; } 12 \text { months, } \mathrm{p}=0.02\end{array}$ \\
\hline $\begin{array}{l}\text { Stanwick et al } \\
\quad(1982), \text { Canada }^{40}\end{array}$ & 4 weeks & $\begin{array}{l}\text { Mother's infant hygiene skills } \\
\text { Knowledge about immunisation }\end{array}$ & No difference \\
\hline $\begin{array}{l}\text { Thompson et al } \\
\text { (1982), USA }\end{array}$ & 30 months & $\begin{array}{l}\text { Mean number of positive statements } \\
\text { Mean number of positive responses }\end{array}$ & $\begin{array}{l}\text { Mean }(\mathrm{SD}) \text { statements: } \mathrm{Int}=5.94(4.6), \mathrm{Con}=3.44(2.58), \mathrm{p}<0.06 \\
\text { Mean }(\mathrm{SD}) \text { responses: } \mathrm{Int}=5.94(4.6), \mathrm{Con}=3.44(2.58), \mathrm{p}<0.06\end{array}$ \\
\hline $\begin{array}{l}\text { Madden et al (1984), } \\
\quad \text { USA }^{41}\end{array}$ & 24 months & $\begin{array}{l}\text { Mother-child interaction } \\
\text { Mother's teaching ability }\end{array}$ & $\begin{array}{l}\text { Mean maternal interaction } \\
\text { 1974: } \text { Int }=324, \text { Con }=216 . \mathrm{F}(1,36)=12.2, \mathrm{p}<0.01 \\
\text { 1975: Int }=352, \text { Con }=178 . \mathrm{F}(1,14)=3.38, \mathrm{p}<0.1 \\
\text { 1976: } \text { Int }=267, \text { Con }=156 . \mathrm{F}(1,40)=18.6, \mathrm{p}<0.001\end{array}$ \\
\hline $\begin{array}{l}\text { Seitz et al (1985), } \\
\quad \text { USA }^{42}\end{array}$ & 10 years & $\begin{array}{l}\text { Involvement with child's schooling only at } \\
\text { request of teacher }\end{array}$ & Int $=1 / 15$, Con $=6 / 15, \chi^{2}=4.59, p<0.05$ \\
\hline $\begin{array}{l}\text { Barker et al }(1988),{ }^{46} \\
\quad(1994), \mathrm{UK}^{50}\end{array}$ & $\begin{array}{l}12 \text { and } 36 \\
\text { months }\end{array}$ & $\begin{array}{l}\text { Mean difference scores on home } \\
\text { socialisation, language, cognitive and } \\
\text { educational environment }{ }^{46} \\
\text { Quality of home reading environment }\end{array}$ & $\begin{array}{l}\text { Significant improvements in cognitive environment in } 1 \text { area at } 36 \text { months } \\
\text { only and in educational environment in } 1 \text { area at } 36 \text { months }{ }^{46} \text { Reported } \\
\text { improvement in quality of reading environment in intervention group (no } \\
\text { significance tests reported) }\end{array}$ \\
\hline $\begin{array}{l}\text { Beckwith (1988), } \\
\text { USA }^{43}\end{array}$ & 1, 9 months & $\begin{array}{l}\% \text { observed talking to child } \\
\% \text { observed holding child } \\
\text { Realistic developmental expectations }\end{array}$ & $\begin{array}{ll}1 \text { month } & 9 \text { months } \\
\text { Int }=47, \text { Con }=31 & \text { Int }=31, \text { Con }=20, \mathrm{~F}(1,60)=3.7, \mathrm{p}<0.05 \\
\text { Int }=57, \text { Con }=47 & \text { Int }=11, \text { Con }=4, \mathrm{~F}(1,60)=4.2, \mathrm{p}<0.05 \\
\text { Int (mean })=2.2, \text { Con }(\text { mean })=1.5, \mathrm{~F}(1,63)=3.9, \mathrm{p}<0.05\end{array}$ \\
\hline $\begin{array}{l}\text { Scarr and } \\
\text { McCartney } \\
(1988), \text { Bermuda }^{44}\end{array}$ & 18 months & $\begin{array}{l}\text { Mother-child interaction } \\
\text { Discipline strategies, mother's teaching } \\
\text { ability }\end{array}$ & $\begin{array}{l}\text { Significantly more intervention group mothers engaged in shared activities } \\
(\mathrm{p}<0.01) \text {. No difference in extent to which mothers relied on physical } \\
\text { punishment as opposed to reasoning. No difference in mother's teaching } \\
\text { ability }\end{array}$ \\
\hline $\begin{array}{l}\text { Sutton (1992), } \\
\text { England }^{47}\end{array}$ & 12,18 months & Application score & $\begin{array}{l}\text { Mean application score: } \mathrm{A}=6.00, \mathrm{~B}=5.50, \mathrm{C}=5.25 \text {, } \mathrm{Con}=11.82 \text {. All } \\
\text { intervention groups had significantly lower score than control group }\end{array}$ \\
\hline $\begin{array}{l}\text { Johnson et al (1993), } \\
\quad \text { Ireland }^{49}\end{array}$ & 12 months & $\begin{array}{l}\text { Percentage reading to child } \\
\text { Mean number (SD) of cognitive games } \\
\text { Mean number (SD) of nursery rhymes }\end{array}$ & $\begin{array}{l}\text { Int }=98 \%(\mathrm{n}=125), \text { Con }=54 \%(\mathrm{n}=57), \mathrm{p}<0.0001 \\
\text { Int }=3.75(2.11), \text { Con }=1.62(1.39), \mathrm{p}<0.01 \\
\text { Int }=7.74(1.65), \text { Con }=3.50(3.24), \mathrm{p}<0.01\end{array}$ \\
\hline $\begin{array}{l}\text { Seeley et al (1996), } \\
\quad \text { England }^{51}\end{array}$ & 4 months & Mother-infant problems & $\begin{array}{l}\text { Significantly fewer mother-infant problems in intervention group }\left(\chi^{2}=13.3 \text {, }\right. \\
1 \mathrm{df}, \mathrm{p}<0.001)\end{array}$ \\
\hline
\end{tabular}

measures also indicated significant improvements in a variety of measures of parenting. While the majority of the studies we reviewed focused on families living in socioeconomic deprivation, it should not be assumed that "poor parenting" is the preserve of such families; or that inequalities in terms of material resources do not need addressing.

Measuring a complex process such as parenting is inevitably difficult. The HOME scale is the standard tool used most frequently for this purpose; however it only measures six dimensions of parenting, and other important aspects of parenting are not measured (and some may not be possible to measure). For this reason we have also included studies reporting other measures of parenting although they have not been included in the meta analyses. It is possible in the studies that we reviewed that social desirability bias may have overestimated the effect of home visiting. Although the HOME score is based on observations of the mother-child interaction and the home environment rather than maternal self reported outcomes, this will not completely remove the bias introduced by the parents' desire to achieve a good outcome, and their consequent "best behaviour" during the observation period. However, these measurements should be less biased than those that rely entirely on maternal self report. Many of the studies that we reviewed did not use blinded outcome assessment, so this may also have led to the introduction of bias. The interpretation of the results from the studies using other measures of parenting is more difficult, but the majority of studies reported positive findings. Unfortunately, where studies reported both HOME scores and other measures of parenting, most papers did not present HOME subscale scores allowing comparisons to be made with their other parenting outcome measures. The use of such a large number of different outcome measures makes comparisons difficult within a systematic review.

The omission of the data necessary for undertaking a meta analysis in many of the studies has limited us to using Fisher's method of meta analysis. Despite attempting to contact authors to request means and standard deviations for total HOME scores and for subscale scores, we were unable to obtain sufficient data to undertake a meta analysis to calculate the size of the overall treatment effect in terms of increasing the HOME score. In future, authors should present this data, as its omission severely limits the use of their findings. Restricting the analysis to Fisher's method also precluded a statistical assessment of heterogeneity between effect sizes and an assessment of the likelihood of publication bias in terms of plotting effect size against sample size. 
Despite the limitations of our systematic review and meta analysis, we have found that home visiting programmes are associated with an increase in the quality of the home environment as measured using the HOME scale and in improving parenting using a range of other measures. The majority of studies we reviewed used professional home visitors, most commonly nurses, but also teachers or social workers. Eight studies used lay workers, and the results of these studies appeared similar to those using professional visitors. Overall, eight studies failed to show a positive effect of home visiting, but they do not appear to be a distinctive group in terms of the characteristics of intervenors, participants, nature, duration, and intensity of intervention or sample size.

Most of the studies did not report repeated measurements of HOME scores over time. This would have been helpful in assessing the duration of the effect of treatment. However, more of the studies reporting follow up periods of less than two years appear to show a treatment effect, ${ }^{15-18} 24-273033$ than those with follow up periods of two years or more..$^{17} 252832$ It is therefore possible that the effect of home visiting on the quality of the home environment reduces over time.

It is difficult to ascertain the content of the home visiting programme, which is effective in improving parenting. Many of the studies we reviewed did not provide a theoretical framework which attempted to hypothesise how the intervention would improve parenting. All of the studies we reviewed were pragmatic in design, in that they offered multifaceted interventions, similar to those already offered by health visitors in a UK context, and similar to those suggested for health visitors, and for Sure Start outreach workers in Supporting Families. ${ }^{5}$ These interventions included education, advice, emotional and social support, "concrete help" (for example, transport to child health clinics, help repairing or obtaining household items, help finding housing, help in securing welfare benefits), increasing formal and informal support, and helping access community services. It is not possible, therefore, to separate out the effect of each of these aspects of the interventions. However, we have shown that the package of interventions was associated with improvements in parenting and the quality of the home environment.

One of the limitations of undertaking a systematic review in the field of home visiting, where many maternal and child health outcomes are assessed, is that by analysing each outcome separately, the relations between the various outcomes are obscured. The relation between improving HOME scores and child and maternal health outcomes is important as the clinical significance of these improved scores is difficult to assess. Looking across the findings from the 102 studies included in our overall review (results will be presented elsewhere), shows that home visiting programmes were also found to be effective in ameliorating child behavioural problems, improving child intellectual development, improving the detection and management of postnatal depression, enhancing the quality of social support for mothers, and reducing the frequency of unintentional injury. It is possible that improvements in these outcomes, for example, providing better maternal support, may help families to parent in a way that enables them to achieve their child care goals more easily, or helps remove the barriers preventing them from achieving their child care goals.

How do the results of this review relate to health visiting in the UK? Only four of these studies used UK health visitors. ${ }^{33465051}$ It is therefore difficult to extrapolate these results to UK health visiting, especially to a universal service, as the majority of studies have concentrated on families at high risk of adverse child and maternal health outcomes. The results of this review do however suggest that home visiting programmes by health visitors may have the potential to improve parenting skills and the quality of the home environment. Lay workers may also be able to achieve similar outcomes. Further work is required assessing the effectiveness of health visitors undertaking home visiting programmes to families considered to be at risk of poor parenting, or those identified at an early stage as having poor parenting skills. Comparisons between health visitors and lay workers are also needed, including an analysis of cost effectiveness.

The results of this review are important as they provide some evidence that there is action that can be taken to improve the parenting we provide for our children. However, the necessity to increase material resources and to improve the environment in which many socioeconomically disadvantaged families live must not be ignored. ${ }^{6}$ Interventions aimed at improving parenting can only ever be part of a wider preventive child health strategy.

This systematic review was funded by the Health Technology Assessment NHS R\&D HTA Programme. The views and opinions expressed here do not necessarily reflect those of the NHS Executive.

1 West DJ, Farrington DP. Who becomes delinquent? London: Heinemann Educational, 1973.

2 Kolvin I, Miller FJW, Scott D, Gratzanis SRM, Fleeting M. Continuities of deprivation. ESRC DHSS studies in deprivation and disadvantages no. 15. Aldershot: Avebury, 1990

3 Scott S. Intensive interventions to improve parenting. Arch Dis Child 1998;79:90-3.

4 Hoghughi M, Speight ANP. Good enough parenting for all children - a strategy for a healthier society. Arch Dis Child 1998; 78:293-300.

5 The Home Office. Supporting families: a consultation document. London: The Stationery Office, 1998.

Blackburn C. Poverty and health. Working with families. Milton Keynes: Open University Press, 1991.

7 Dickersin K, Scherer E, Lefebvre C. Identification of Dickersin K, Scherer E, Lefebvre C. Identification of
relevant studies for systematic reviews. BMf 1994;309: relevant $1286-91$.

8 Barlow J. Systematic review of the effectiveness of parenttraining programmes in improving behaviour problems in children aged 3-10 years. Oxford: Health Services Research Unit, Oxford University, 1997.

9 Community Practitioners and Health Visitors Association. Making the difference: evidence of the effectiveness of health visiting. London: CPHVA, 1998.

10 Combs-Orme T, Reis J, Ward LD. Effectiveness of home visits by public health nurses in maternal and child health: an empirical review. Public Health Rep 1985;100:490-9.

11 Hodnett ED. Support from caregivers for socially disadvantaged mothers. The Cochrane pregnancy and childbirth database, Issue 2. 1995

12 Olds DL, Kitzman H. Review of research on home visiting for pregnant women and parents of young children in "The fut pregnant women and parents of young children". Home Visiting 1993;3:53-92.

13 Reisch JS, Tyson JE, Mize SG. Aid to the evaluation of therapeutic studies. Pediatrics 1989;84:815-27. 
14 Bradley R, Caldwell B. Home observation for the measurement of the environment: a revision of the pre-school scale. ment of the environment: a revision

15 Field TM, Widmayer SM, Stringer S, Ignatoff E. Teenage, lower class, black mothers and their preterm infants: an intervention and developmental follow up. Child Dev 1980; 51:426-36.

16 Larson CP. Efficacy of prenatal and postpartum home visits on child health and development. Pediatrics 1980;66:1917.

17 Field TM, Widmayer SM, Greenberg R, Stoller S. Effects of parent training on teenage mothers and their infants. Pediatrics 1982;69:703-7.

18 Barrera ME, Rosenbaum PL, Cunningham CE. Early home intervention with low birth weight infants and their parents. Child Dev 1986;57:20-33.

19 Olds DL, Henderson CR, Chamberlain R, Tatelbaum R. Preventing child abuse and neglect: a randomised trial of Preventing child abuse and neglect: a randomised

20 Olds DL, Henderson CR, Kitzman H. Does prenatal and infancy nurse home visitation have enduring effects on infancy nurse home visitation have enduring effects on qualities of parental caregiving and child

21 Barnard KE, Magyray D, Sumner G, et al. Prevention of parenting alterations for women with low social support. Psychiatry 1988;51:248-53.

22 Booth CL, Mitchell SK, Barnard KE, Spieker SJ. Development of maternal social skills in multiproblem families: effects on the mother child relationship. Dev Psychol 1989; 25:403-12.

23 Osofsky JD, Culp AM, Ware LM. Intervention challenges with adolescent mothers and their infants. Psychiatry 1988 51:236-41

24 Infante-Rivard C, Filion G, Baumgarten M, Bourassa M, Labelle J, Messier M. A public health home intervention among families of low socio-economic status. Child Health Care 1989;18:102-7.

25 Wasik BH, Ramey CT, Bryant DM, Sparling JJ. A longitudinal study of two intervention strategies: project CARE. nal study of two intervention

26 Huxley P, Warner R. Primary prevention of parenting dysfunction in high-risk cases. Am $\mathcal{F}$ Orthopsychiatry 1993 63:582-7

27 Black MM, Nair P, Kight C, Watchel R, Roby P, Schuler M Parenting and early development among children of drug abusing women: effects of home intervention. Pediatrics 1994;94:440-7.

28 Casey PH, Kelleher KJ, Bradley RH, et al. A multifaceted intervention for infants with failure to thrive. Arch Pediat Adolesc Med 1994;148:1071-7.

29 Marcenko MO, Spence M. Home visitation services for at-risk pregnant and postpartum women: a randomised trial. Am f Orthopsychiatry 1994;64:468-78.

30 Black MM, Dubowitz H, Hutcheson J, Berenson-Howard J, Starr H. A randomised clinical trial of home intervention for children with failure to thrive. Pediatrics 1995;95:807for chil 13 .

31 Shapiro C. Shortened hospital stay for low birth weight infants: nuts and bolts of a nursing intervention project. Fournal of Obster

32 Kitzman H, Olds DL, Henderson CR, et al. Effect of prenatal and infancy home visitation by nurses on pregnancy outcomes, child injuries and repeated childbearing. A randomised controlled trial. FAMA 1997;278:644-52
33 Davis H, Spurr P. Parent counselling: an evaluation of a community child mental health service. F Child Psychol Psychiatry 1998;39:365-76.

34 McNeil HJ, Holland S. A comparative study of public health nurse teaching in groups and in home visits. Am f Public Health 1972;62:1629-36

35 Grantham-McGregor SM, Desai P. A home visiting intervention programme with Jamaican mothers and children. Devel Med Child Neurol 1975;17:605-13.

36 Gutelius MF, Kirsch AD, McDonald S, Riddick Brooks M, McErlan T. Controlled study of child health supervision: behaviour results. Pediatrics 1977;60:294-304.

37 Siegel E, Bauman KE, Schaefer ES, Saunders MM, Ingram D. Hospital and home support during infancy: impact on maternal attachment, child abuse and neglect and health care utilisation. Pediatrics 1980;66:183-90.

38 Hall LA. Effect of teaching on primiparas' perceptions of their newborn. Nurs Res 1980;29:317-22.

39 Law-Harrison L, Twardosz S. Teaching mothers about their preterm infants. Fournal of Obstetric, Gynaecologic and Neonatal Nursing 1986;15:165-71.

40 Stanwick RS, Moffat MEK, Robitaille Y, Edmond A, Dok C. An evaluation of the routine post-natal public health nurse home visit. Can F Public Health 1982;73:200-5.

41 Madden J, O'Hara J, Levenstein P. Home again: effects of the mother-child home programs on mother and child. Child Dev 1984;55:636-47.

42 Seitz V, Rosenbaum LK, Apfel NH. Effects of family support intervention: a ten-year follow up. Child Dev 1985; 56:376-91.

43 Beckwith L. Interventions with disadvantaged parents of sick preterm infants. Psychiatry 1988;51:242-7.

44 Scarr S, McCartney K. Far form home: an experimental evaluation of the Mother Child Home Program in Bermuda. Child Dev 1988;59:531-43.

45 Resnick MB, Armstrong S, Carter RL. Developmental intervention program for high-risk premature infants: effects on development and parent-infant interactions. Developmental and Behavioural Pediatrics 1988;9:73-8.

46 Barker W, Anderson R. The child development programme: an evaluation of process and outcome. Evaluation document 9. Bristol: Earty

47 Sutton C. Training parents to manage difficult children: a comparison of methods. Behavioural Psychotherapy 1992; 20:115-39.

48 Thompson RJ, Cappleman MW, Conrad HH, et al. Early intervention program for adolescent mothers and their infants. Developmental and Behavioral Pediatrics 1982;3:1821

49 Johnson Z, Howell F, Molloy B. Community mothers' programme: randomised controlled trial of nonprofessional intervention in parenting. $B M \mathcal{F}$ 1993;306: 1449-52.

50 Barker W, Anderson R, Chalmers C. EHSSB: health trends over time and major outcomes of the child development programme. Early health and development monitor. Evaluation document no. 15. Bristol: Early Child Development Unit, University of Bristol and Eastern Health and Social Services Board, 1994.

51 Seeley S, Murray L, Cooper PJ. The outcome for mothers and babies of health visitor intervention. Health Visit 1996; 69:135-8 